ПЕТРИК В. Л. ${ }^{1}$

\title{
СТАТИСТИЧНИЙ АНАЛІЗ АВІАЦЙНОЇ ГАЛУЗІ УКРАЇНИ В УМОВАХ НЕСТАБІЛЬНОГО ПОПИТУ НА АВІАПЕРЕВЕЗЕННЯ
}

\author{
DOI: $10.32620 /$ cher.2021.4.06
}

Постановка проблеми. Постійний моніторинг стану й тенденцій розвитку авіаційної галузі України, особливо в умовах нестабільного попиту на авіаперевезення, якій викликаний пандемією короновірусної інфекції COVID-19, дозволяє авіаційним підприємствам України своєчасно реагувати на зміни й за необхідності моделювати свою бізнес-модель поведінки на ринку. 3 часом значення й роль авіації в розвитку економіки України буде тільки зростати, тому необхідним є своєчасне дослідження й прогнозування ринку повітряних перевезень з метою підвищення їх економічної ефективності $\mathrm{Me-}$ тою статті є аналіз закономірностей й тенденцій, притаманних сучасному ринку авіаційних перевезень України, та прогноз його розвитку в умовах нестабільного попиту на авіаперевезення. Методологічною основою дослідження стали логічні методи обробки інформації, статистичний аналіз, методи системного аналізу, порівняння. Основною гіпотезою дослідження стало припущення, що на розвиток авіаційної галузі України впливає нестабільний попит на внутрішньому та міжнародному ринках авіаперевезень. Виклад основного матеріалу. Проаналізовано основні показники діяльності підприємств авіаційної галузі України, динаміка перевезень українськими авіакомпаніями на внутрішньому та міжнародному ринку авіаперевезень. Визначено, що розвиток цивільної авіації пов'язаний iз загальними тенденціями міжнародного повітряного транспорту і обумовлений як загальносвітовими, так і внутрішньодержавними соціально-економічними, політичними та іншими факторами. Оригінальність та практичне значення дослідження. Проведені дослідження доцільно використовувати при визначенні засад управління авіаційними підприємствами для зміни пріоритетів їх господарської діяльності. Висновки. Проведений аналіз вітчизняних авіаперевезень показав, що незважаючи на нестабільність економічної ситуації в країні та в світі, темпи зростання обсягу авіаперевезень в українському сегменті ринку мають позитивну тенденцію. Для вітчизняного авіаційного транспорту $\epsilon$ перспективи подальшого розвитку та зміцнення позицій у світовій системі повітряних перевезень.

Ключові слова:

цивільна авіація, авіакомпанія, авіаперевезення, пасажиропотік, стратегія розвитку.

\section{STATISTICAL ANALYSIS OF THE UKRAINE'S AIRCRAFT INDUSTRY IN CONDITIONS OF UNSTABLE DEMAND FOR AIR TRANSPORTATION}

Formulation of the problem. Constant monitoring of the state and development trends of the aviation industry in Ukraine, especially in the context of unstable demand for air transportation caused by the coronavirus infection COVID-19 pandemic, allows aviation enterprises of Ukraine to respond in a timely manner to changes and, if necessary, model their business model of behavior in the market. Over time, the importance and role of aviation in the development of the Ukrainian economy will only increase, therefore, timely research and forecasting of the air transportation market is necessary in order to increase their economic efficiency. The aim of the article is to analyze the patterns and trends inherent in the modern air transportation market in Ukraine, and forecast its development in the context of unstable demand for air transportation. Methodological basis of research was logical methods of information processing, statistical analysis, methods of system analysis, comparison. The basic hypothesis of research was the assumption that the development of the aviation industry in Ukraine is influenced by unstable demand in the domestic and international air transportation markets. Presentation of the main material. The main indicators of the

${ }^{1}$ Петрик Валерія Леонідівна, канд. техн. наук, доцент, доцент кафедри економіки, маркетингу та міжнародних економічних відносин, Національний аерокосмічний університет ім. М.Є. Жуковського «Харківський авіаційний інститут», м. Харків, Україна.

Petryk Valeriia, Ph.D. of Technical Sciences, Associate Professor, Associate Professor of Economics, Marketing and International Economic Relations Department, National Aerospace University «Kharkiv Aviation Institute», Kharkiv, Ukraine.

ORCID ID: 0000-0002-8376-7148

e-mail: v.petryk@khai.edu 
activities of enterprises of the aviation industry of Ukraine, the dynamics of transportation by Ukrainian airlines in the domestic and international air transportation market are analyzed. It was revealed that the development of civil aviation is associated with general trends in international air transport and is due to both global and domestic socio-economic, political and other factors. Originality and practical meaningfulness of research. . It is advisable to use the conducted research in determining the principles of management of aviation enterprises to change the priorities of their economic activities. Conclusions. The analysis of domestic air transportation showed that, despite the instability of the economic situation in the country and the world, the growth rate of air transportation in the Ukrainian segment of the market has a positive trend. For domestic air transport, there are prospects for further development and strengthening of positions in the world air transportation system.

Key words:

civil aviation, airline, air transportation, passenger traffic, development strategy.

\section{СТАТИСТИЧЕСКИЙ АНАЛИЗ АВИАЦИОННОЙ ОТРАСЛИ УКРАИНЫ В УСЛОВИЯХ НЕСТАБИЛЬНОГО СПРОСА НА АВИАПЕРЕВОЗКИ}

Постановка проблемы. Постоянный мониторинг состояния и тенденций развития авиационной отрасли Украины, особенно в условиях нестабильного спроса на авиаперевозки, вызванного пандемией короновирусной инфекции COVID-19, позволяет авиационным предприятиям Украины своевременно реагировать на изменения и, при необходимости, моделировать свою бизнес-модель поведения на рынке. Со временем значение и роль авиации в развитии экономики Украины будет только возрастать, поэтому необходимо своевременное исследование и прогнозирование рынка воздушных перевозок с целью повышения их экономической эффективности. Целью статьи является анализ закономерностей и тенденций, присущих современному рынку авиационных перевозок Украины, и прогноз его развития в условиях нестабильного спроса на авиаперевозки. Методологической основой исследования явились логические методы обработки информации, статистический анализ, методы системного анализа, сравнения. Основной гипотезой исследования стало предположение, что на развитие авиационной отрасли Украины влияет нестабильный спрос на внутреннем и международном рынках авиаперевозок. Изложение основного материала. Проанализированы основные показатели деятельности предприятий авиационной отрасли Украины, динамика перевозок украинскими авиакомпаниями на внутреннем и международном рынке авиаперевозок. Віявлено, что развитие гражданской авиации связано с общими тенденциями международного воздушного транспорта и обусловлено как общемировыми, так и внутригосударственными социально-экономическими, политическими и другими факторами. Оригинальность и практическое значение исследования. Проведенные исследования целесообразно использовать при определении принципов управления авиационными предприятиями для изменения приоритетов их хозяйственной деятельности. Bblвoды. Анализ отечественных авиаперевозок показал, что, несмотря на нестабильность экономической ситуации в стране и мире, темпы роста объема авиаперевозок в украинском сегменте рынка имеют положительную тенденцию. Для отечественного авиационного транспорта имеются перспективы дальнейшего развития и укрепления позиций в мировой системе воздушных перевозок.

\section{Ключевые слова:}

гражданская авиация, авиакомпания, авиаперевозки, пассажиропоток, стратегия развития.

Постановка проблеми. Цивільна авіація є однією з складових частин глобальної транспортної системи, яка забезпечує робочими місцями та впливає на розвиток світової економіки будь якої країни світу. Авіаційна галузь України належить до базових, стратегічно важливих секторів економіки, має значний інноваційний потенціал розвитку. Але через незадовільний стан авіаційної інфраструктури, системні проблеми з фінансування, планування та управління використовується недостатньо, а сама галузь потребує масштабного реформування. До того ж пандеміологі- чна ситуація в світі, пов'язана із спалахом гострої респіраторної хвороби COVID-19, та обмеження, що запроваджуються державами задля протидії ії розповсюдженню, безпосередньо вплинули на авіаційну галузь країн світу, у тому числі й України, де за підсумками 2020 року спостерігалось суттєве скорочення виробничих показників діяльності авіаційних підприємств порівняно з попереднім роком. Тому постійний моніторинг стану й тенденцій в галузі авіаційних перевезень, особливо в умовах нестабільного попиту на авіаперевезення, дозволяє підприємствам України своєчасно реагувати на зміни й за необхідності моделювати 
свою бізнес-модель поведінки на ринку. 3 часом значення й роль авіації в розвитку економіки України буде тільки зростати, тому необхідним є своєчасне дослідження й прогнозування ринку повітряних перевезень 3 метою підвищення їх економічної ефективності.

Аналіз останніх досліджень та публікацій. Дослідженню стану та проблем авіаційної галузі у світі та в Україні присвячено праці таких вітчизняних вчених, як Ю. Кулаєв [1-2], В. Загорулько [2], О. Костроміна [3], Н. Солідор [4], М. Орловський [5], Т. Олешко та інші. Більшість із зазначених авторів в своїх працях відмічають що, пасажирські авіаперевезення одними 3 перших реагують на зміну макроекономічного клімату. Також дослідженнями в авіаційній сфері займаються такі провідні міжнародні організації, як Міжнародна організація цивільної авіації (International Civi Aviation Organization, ICAO), Міжнародна асоціація повітряного транспорту (International Air Transportation Association, IATA), Ініціативна група 3 питань повітряного транспорту (Air transport action group, ATAG). Щорічно Державна авіаційна служба України оприлюднює підсумки діяльності авіаційної галузі України. Однак, треба відзначити недостатню теоретичну опрацьованість сучасних тенденцій розвитку українського ринку цивільної авіації в умовах нестабільного попиту на авіаперевезення, його місця на світовому ринку, а також проблем і перспектив його розвитку в умовах глобальних трансформацій [6].

Метою дослідження $\epsilon$ аналіз сучасного стану авіаційної галузі України та прогноз його розвитку в умовах нестабільного попиту на авіаперевезення, якій викликаний пандемією короновірусної інфекції COVID-19.

Виклад основного матеріалу дос-лідження. Україна належить до небагатьох країн світу, що володіють повним циклом (макротехнологією) створення авіаційної техніки, і займає провідне місце на світовому ринку в секторі транспортної та регіональної пасажирської авіації [5].

Цивільна авіація, маючи складні взаємозв'язки 3 іншими галузями, сприяє економічному розвитку держав. Підвищення рівня доходу і виробництва тягне за собою розширення попиту на авіаційні види обслуговування. Одночасно, сприяючи розвитку туризму, торгівлі та трудової зайнятості, авіація стає важливим інструментом економічного розвитку. Крім того, повітряний транспорт сприяє розширенню міжнародних контактів i взаєморозумінню [6].

Цивільна авіація у даний час є однією 3 найбільш важливих галузей національної економіки, досягнення якої роблять ії ефективним інструментом розвитку сучасного суспільства. Економічний ефект від діяльності галузі авіаперевезень у 2018 році становив понад 1474,9 млн грн. Галузь безпосередньо та опосередковано забезпечує до 108 тис робочих місць по всієї Україні [7].

Починаючи 32016 року ринок пасажирських авіаперевезень України розвивався досить динамічно після спаду 2014-2015 p.p. (таблиця 1) Якщо за підсумками 2016 року обсяги пасажирських перевезень вітчизняних авіакомпаній перевищили показник „докризового" 2013 року на $2,06 \%$, то за 2017 рік - вже на $30,1 \%$, за 2018 рік - на 54,5\%, у 2019 році на $68,9 \%$. Поступово обсяги пасажирських перевезень до 2019 збільшились більш ніж у два рази в порівнянні з показником 2015 року та більш як у півтора разу перевищили рівень „докризового” 2013 року [8].

У 2019 році ринок пасажирських авіаперевезень продовжував демонструвати позитивну динаміку. Кількість пасажирів, що скористались послугами українських авіакомпаній, збільшилась відносно 2018 року на 9,39\% та склала 13705,8 тис. чоловік (рисунок 1) [8].

У 2019 році міжнародні регулярні пасажирські перевезення здійснювали 10 вітчизняних авіакомпаній до 46 країн світу. Найбільші обсяги виконано авіакомпаніями «Міжнародні авіалінії України», «Азур Ейр Україна», «Скайап», «Роза вітрів» та «Буковина». Кількість пасажирів, які скористались послугами українських компаній, зросла на 4,6\% відсотка та становила 7107,2 тис. чоловік.

Регулярні внутрішні пасажирські перевезення між 11 містами України виконували чотири вітчизняні авіакомпанії («Міжнародні авіалінії України», «Мотор Січ», «Роза вітрів» та «Скайап»). Протягом 2019 року регулярними рейсами у межах України перевезено 1145,2 тис. пасажирів, що на 6,9\% більше, ніж за попередній рік [8].

У кінці 2019 р. IATA випускає оптимістичний прогноз на 2020 р., згідно з яким світова авіація готувалася збільшити виручку на 4\% до 872 млрд доларів і заробити чистий прибуток в розмірі 29,3 млрд. дол. США. 
Таблиця 1 - Основні показники діяльності авіаційної галузі України (2016-2020 рр.)

\begin{tabular}{|c|c|c|c|c|c|}
\hline Показник & 2016 & 2017 & 2018 & 2019 & 2020 \\
\hline $\begin{array}{l}\text { Кількість вітчизняних авіакомпаній, що } \\
\text { здійснювали пасажирські та вантажні пе- } \\
\text { ревезення }\end{array}$ & 29 & 32 & 34 & 29 & 26 \\
\hline $\begin{array}{l}\text { Кількість вітчизняних авіакомпаній, що } \\
\text { здійснювали пасажирські перевезення }\end{array}$ & 19 & 18 & 21 & 18 & 14 \\
\hline Чистий прибуток (збиток), млн. грн & 1246,9 & $-959,3$ & $-1722,8$ & 2623,6 & \multirow{2}{*}{$\begin{array}{c}\text { Інфор- } \\
\text { мація ві- } \\
\text { дсутня }\end{array}$} \\
\hline $\begin{array}{l}\text { Рівень рентабельності (збитковості) всієї } \\
\text { діяльності підприємств }\end{array}$ & 3,8 & $-2,2$ & $-3,1$ & 4,9 & \\
\hline $\begin{array}{l}\text { Середньооблікова кількість штатних } \\
\text { працівників }\end{array}$ & 7,1 & 8,2 & 8,1 & 16,2 & 16,0 \\
\hline $\begin{array}{l}\text { Темпи зростання середньомісячної заро- } \\
\text { бітної плати штатних працівників }\end{array}$ & & 25,92 & 14,68 & $-23,42$ & $-20,6$ \\
\hline $\begin{array}{l}\text { Кількість відправлених та прибулих пові- } \\
\text { тряних суден, тис }\end{array}$ & 133,2 & 159,9 & 182,8 & 201,2 & 94 \\
\hline $\begin{array}{l}\text { Темпи зростання кількості відправлених } \\
\text { та прибулих повітряних суден, \% }\end{array}$ & 10,36 & 20,05 & 14,32 & 10,07 & $-53,28$ \\
\hline Перевезено пасажирів, тис. чол. & 8277,8 & 10556,3 & 12529,0 & 13705,8 & 4797,5 \\
\hline $\begin{array}{l}\text { Темпи зростання кількості перевезених } \\
\text { пасажирів, \% }\end{array}$ & 31,30 & 27,53 & 18,73 & 9,35 & $-65,00$ \\
\hline Пасажиропотоки, тис. чол. & 12929,9 & 16498,9 & 20545,4 & 24334,5 & 8664,50 \\
\hline Темпи зростання пасажиропотоку, \% & 20,90 & 27,60 & 24,53 & 18,44 & $-64,39$ \\
\hline $\begin{array}{l}\text { Коефіцієнт завантаження пасажирських } \\
\text { крісел, \% }\end{array}$ & 73,3 & 77,5 & 78,9 & 80,7 & 68,4 \\
\hline $\begin{array}{l}\text { Пасажирообіг (Виконані пасажиро-кіло- } \\
\text { метри, млн. пас.км) }\end{array}$ & 15500 & 20347,0 & 25889,3 & 30241,8 & 10106,9 \\
\hline Приріст RPK (Пасажирообігу), \% & 36,0 & 31,3 & 27,2 & 16,8 & $-66,6$ \\
\hline
\end{tabular}

Джерело: розраховано автором на підставі [8-9]

Після чотирьох років стрімкого зростання авіаційна галузь України також очікувала збільшення показників у 2020 році [10].

Однак 2020 рік був дуже несприятливим для авіаційної галузі України. Внаслідок поширення короновірусної інфекції COVID-19, відбулося значне скорочення основних показників ії роботи. 3 початку 2020 року припинила свою роботу частина вітчизняних аеропортів, багато авіаперевізників значно скоротили маршрутну мережу, низку напрямків взагалі було згорнуто. За кілька місяців 2020 року практично повністю зупинилися повітряні перевезення у більшості країн світу, у тому числі Україні. Так, за перший квартал 2020 року скорочення пасажирських перевезень українських авіакомпаній в порівнянні 3 аналогічним періодом 2019 року становило 17,7\%, за другий квартал, на який припав пік обмежувальних заходів, - 98,3\%. Проте, після відновлення пасажирського авіасполучення у червні місяці, темпи спаду обсягів перевезень за результатами третього і четвертого кварталів склали $61,4 \%$ 66,2\% [8].

Упродовж 2020 року українські авіакомпанії виконали 45277 рейсів, що в 2,81 разів менше порівняно з 2019 роком. Пасажиропотоки через аеропорти України скоротилися на $64,39 \%$ та становили 8664,50 тис пасажирів, обсяги пасажирських перевезень українських авіакомпаній зменшилися порівняно 3 попереднім роком на $65 \%$ та сягали 4797,7 тис пасажирів. Отже, можна зробити висновок, що загальне падіння авіаційних перевезень на українському ринку становило 65\%.

У 2021 році авіаційна галузь зосереджена на тих же проблемах, що й протягом другої половини 2020: управління щоденними фінансовими втратами, підвищення рівня безпеки та пропонування привабливих цін, що мають на меті повернути пасажирський попит [11]. Кількість польотів на початок 2021 року становив лише 50 \% від рівня 2019 р. [12]. 


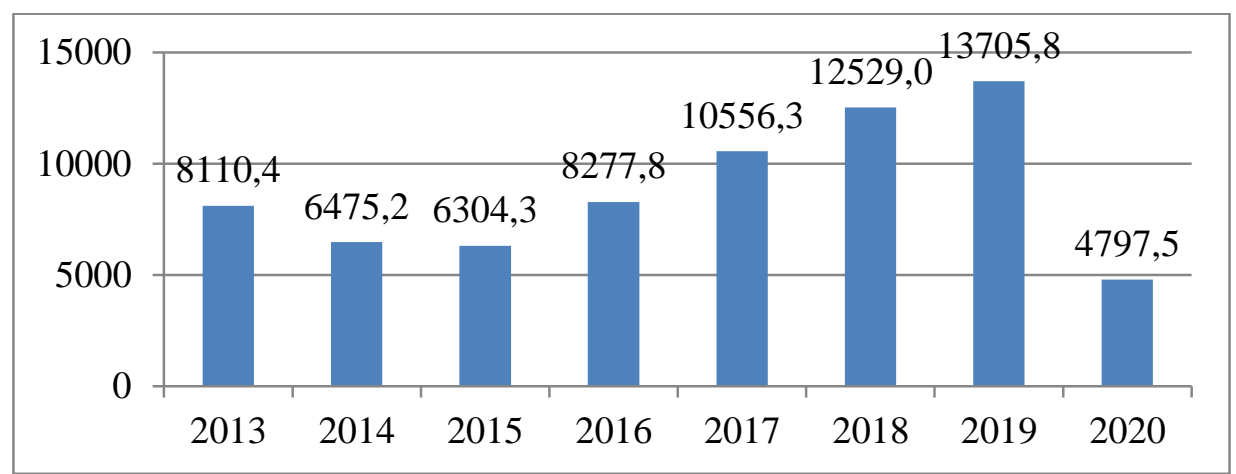

Рисунок 1 - Динаміка обсягів перевезень пасажирів українськими авіакомпаніями, тис. осіб Джерело: розроблено автором

Однак спостерігається й значне покрашення показників. За січень - вересень 2021 року обсяги пасажирських перевезень українських авіакомпаній збільшились порівняно з відповідним періодом минулого року на $93 \%$ та склали 7277,5 тис. чол., у т.ч. міжнародні перевезення збільшились на 99,3\% та склали 6737,8 тис. чол. Пасажиропотоки через аеропорти України зросли на $72,3 \%$ та становили 11816,1 тис. чол., У т.ч. у міжнародному сполученні виросли на $76,8 \%$ та становили 10723,4 тис. чол. [8].

За девять місяців 2021 року українськими авіакомпаніями виконано 56,3 тисяч комерційних рейсів, що на 64,6\% більше порівняно з аналогічним періодом минулого року, у тому числі міжнародних -46 тисяч $(+69,1 \%)$. Збільшенню кількості польотів у 2021 році сприяла група факторів: сезонність попиту на авіаперевезення, послаблення карантинних обмежень у багатьох країнах світу, прийняття авіапасажирами нових пандемічних реалій і правил подорожей, вихід на ринок України нових авіаперевізників, зменшення ставок за аеронавігаційне обслуговування на маршруті для польотів в окремій частині повітряного простору України над акваторією Чорного моря. Збільшення кількості комерційних рейсів $\epsilon$ в тому числі результатом державної політики з розвитку регіональних аеропортів та заохочення внутрішнього туризму [12].

3 огляду на «низький сезон» зимової навігації та запровадження нових коронавірусних обмежень, IV квартал 2021 та I квартал 2022 прогнозуються неприбутковими для всіх учасників авіаційного ринку. Проте, Державне підприємство обслуговування повітряного руху України (Украерорух) очікує на прибуткову діяльність у майбутньому, а також повернення докризового рівня оплати праці на підприємстві. Цьому сприяє наявність дій щодо збільшення інтенсивності польотів та подальшого розвитку транзитного потенціалу повітряного простору України [12]:
- антикризові заходи, спрямовані на оптимізацію всіх видатків;

- ефективне використання залучених кредитних коштів для підтримання ліквідності підприємства;

- запровадження Міністерством інфраструктури України економічно обгрунтованих ставок за аеронавігаційне обслуговування над Чорним морем 3 червня 2021 року;

- системна робота 3 українськими та іноземними авіакомпаніями 3 метою їх залучення до використання повітряного простору України, що втричі збільшило кількість польотів у повітряному просторі над Чорним морем;

- фінансова дисципліна в розрахунках із боку партнерів-авіакомпаній.

Міжнародна асоціація повітряного транспорту (IATA) передбачає, що рівень авіаперевезень повернеться на докризовий лише до 2024 р.

Висновки та перспективи подалыших досліджень. Розвиток авіаційної галузі сприяє поліпшенню показників соціально-економічного розвитку міст України, їі інвестиційної та туристичної привабливості та $€$ сьогодні необхідною умовою реалізації інноваційної моделі економічного зростання України. Ураховуючи сучасні тенденції світової глобалізації, особливості географічного положення України як «мосту» між Європою й Азією, для вітчизняного авіаційного транспорту є перспективи подальшого розвитку та зміцнення позицій у світовій системі повітряних перевезень. Однак коронакриза ще раз продемонструвала, що безпека польотів, авіаційна безпека, охорона здоров'я тощо впливають на попит авіаперевезень помітніше, ніж економічні процеси. Фактичні довгострокові наслідки для галузі залежатимуть від тривалості та масштабу коронакризи та заходів ii стримування, ступеня довіри споживачів до безпеки повітряних перевезень та економічних умов. У більшості країн пандемія все ще продовжується. Сьогодні в Україні спостерігається стрімке поширення хвороби. Тому зрозуміло, що реальні перспективи зростання показників 
авіаційної галузі можливі лише тоді, коли мине пандемія та економіка відновиться.

\section{Література}

1. Кулаєв Ю. Ф. Экономика гражданской авиации Украины. Київ: Вид-во «Фенікс», 2004. $667 \mathrm{c}$.

2. Основи економіки транспорту: підручник / В. І. Щелкунов, Ю. Ф. Кулаєв, Л. Г. Зайончик, В. М. Загорулько [та ін.]. Київ: Кондор, 2011. 392 с.

3. Костромина Е. В. Экономика авиакомпаний в условиях рынка. 4-е изд. Москва: НОУВКШ «Авиабизнес», 2002. 304 с.

4. Солідор Н. А. Сучасний стан, проблеми та перспективи інноваційного розвитку авіаційної галузі України. Науковий вісник Ужгородського національного університету. Серія: Міжнародні економічні відносини та світове господарство. 2020. Вип. 30. С. 160-165.

5. Хрістов В. О. Орловський М. М., Приймак А. В. Аналіз сучасного стану авіаційних перевезень в Україні. Открытые информационные и компьютерные интегрированные технологии. 2020. № 87. С. 110-120.

6. Петрик В. Л. Аналіз стану світового ринку цивільної авіації та прогноз його розвитку в умовах нестабільного попиту на авіаперевезення. Бізнес Інформ. 2020. №3. С. 112-119.

7. IATA. The Importance of Air Transport to Ukraine. [Електронний ресурc]. URL: https://www.iata.org/en/iata-

repository/publications/economic-reports/ukraine-value-of-aviation/

8. Офіційний сайт Державної авіаційної служби України. [Електронний ресурс]. URL: https://avia.gov.ua

9. Офіційний сайт Державного комітету статистики України [Електронний ресурс]. URL: https://www.ukrstat.gov.ua

10. IATA. Industry Statistics Fact Sheet. [Електронний ресурc]. URL: https://www.iata.org/en/iatarepository/pressroom/fact-sheets/fact-sheet-

11. Круте піке: як авіаційна галузь пережила 2020 рік. [Електронний ресурс]. URL: https://mintrans.news/avia/krute-pike-yakaviatsiina-galuz-perezhila-2020-rik
12. Офіційний сайт Міністерства інфраструктури України. [Електронний ресурс]. URL: https://mtu.gov.ua/timeline/Aviatransport.html

\section{References}

1. Kulayev, Yu.F. (2004). Economics of Civil Aviation of Ukraine. Kyiv: «Fenix», 667.

2. Shchelkunov, V. I., Kulaev, Y. F., Zayonchik, L. G. and Zagorulko, V. M. (2011). Fundamentals of transport economics: a textbook. Kyiv: Kondor, 392.

3. Kostromina, E. V. (2002). The economy of airlines in market conditions. 4th ed. Moscow: NOUVKSH "Aviabusiness", 304.

4. Solidor, N. A. (2020). Current state, problems and prospects of innovative development of the aviation industry of Ukraine. Scientific Bulletin of Uzhgorod National University. Series: International Economic Relations and the World Economy, 30, 160-165.

5. Hristov, V. O., Orlovsky, M. M. and Priymak, A. V. (2020). Analysis of the current state of air transportation in Ukraine. Open information and computer integrated technologies, 87, 110-120.

6. Petryk, V. L. (2020). Analysis of the world market of civil aviation and forecast of its development in conditions of unstable demand for air transportation. Business Inform, 3, 112-119.

7. IATA. The Importance of Air Transport to Ukraine. Retrieved from: https://www.iata.org/en/iata-

repository/publications/economic-reports/ukraine-value-of-aviation/

8. Official Site of the State Aviation Service of Ukraine. Retrieved from: https://avia.gov.ua

9. Official site of the State Statistics Committee of Ukraine. Retrieved from : https://www.ukrstat.gov.ua

10. IATA. Industry Statistics Fact Sheet. Retrieved from : https://www.iata.org/en/iatarepository/pressroom/fact-sheets/fact-sheetindustry-statistics/

11. Steep peak: how the aviation industry survived 2020. Retrieved from: https://mintrans.news/avia/krute-pike-yakaviatsiina-galuz-perezhila-2020-rik

12. Official site of the Ministry of Infrastructure of Ukraine. Retrieved from: https://mtu.gov.ua/timeline/Aviatransport.html.

Стаття прийнята

до друку: 30.12.2021 p.

\section{Бібліографічний опис для цитування :}

Петрик В. Л. Статистичний аналіз авіаційної галузі України в умовах нестабільного попиту на авіаперевезення / В. Л. Петрик // Часопис економічних реформ. - 2021. - № 4(44). - С. 40-45. 